\title{
Housing delivery system, need and demand
}

\author{
Olusola Oladapo Makinde
}

Received: 11 September 2012/ Accepted: 11 June 2013/Published online: 3 July 2013

(C) The Author(s) 2013. This article is published with open access at Springerlink.com

\begin{abstract}
This paper reviews the past and current housing delivery programmes in Nigeria and analysed the demand and supply issues. The paper examined factors responsible for high housing pricing trends, it state the constraints and challenges in accessing housing. The paper ascertains guiding principles for implementation towards quality housing delivery, and it identifies the various housing delivery mechanisms in current practice and suggests a holistic programme to address the huge housing shortage in Nigeria. The study addresses the problem of housing delivery systems, the supply and the demand issues with a view to inform policy on housing provision structure, want and request towards improving the level of delivery in Nigeria. The methodology adopted for the study includes interviews and analyses of data collected during the field investigations. These investigations were complemented with review of literature. The data required for this study were obtained primarily from secondary source and personal observations. Suggestions were put forward on policy measures that can sustain future planning of housing provision in Nigeria to conform to what is obtain in other part of the world.
\end{abstract}

Keywords Housing · Delivery system $\cdot$ Need $\cdot$ Demand

\section{Introduction}

In a developing country like Nigeria, the housing problem basically relates to quantitative and qualitative insufficiencies. On the supply side, various government strategies in the past have been formulated towards overcoming the enormous shortage through several housing reform programmes. Despite these past efforts, housing continues to be a mirage to ordinary Nigerian. Presently, there are various mass housing delivery programmes such as

\section{O. O. Makinde $(\bowtie)$}

Department of Architecture, Ladoke Akintola University of Technology, Ogbomosho,

Oyo State, Nigeria

e-mail: makindeolusola2012@yahoo.com 
the affordable housing scheme that utilise the public-private partnership effort and numerous private finance initiative models that could only provide for about $3 \%$ of the required stock. This suggests the need for a holistic solution in approaching the problem. While the quality of the existing stock is also under a heavy study in terms of design and desired functions including satisfactory liveable neighbourhood, $87 \%$ of the existing stocks are accumulations which are frameworks that do not meet the minimum quality requirement (Olayiwola 2005 and Daramola 2004).

The right to adequate housing that is safe, secure, healthy, available and inexpensive is enshrined in the Habitat Agenda the global call on human settlement and shelter (UNHabitat 2001). According to Pison Housing Company (2010), there are about 10.7 million houses in Nigeria. Irrespective of the policies, organisations and regulations which the Nigerian government has put in place since independence in 1960, there is still a shortage of housing, especially for the low-income section. The Federal Mortgage Bank of Nigeria (FMBN), which is answerable for the provision of mortgages to low-income earners through the National Housing Trust Fund (NHTF), has operational and financial capability restraints that limit its efficiency. With this, the few low-income earners who own their houses usually obtain land and build incrementally with their funds, while the high-income house-owners buy with money, or mortgage finance, usually pay back over a maximum period of 10 years (Enuenwosu 1985; Falegan 1980 and Akinlusi 2007).

A major short coming has been with ownership rights under the Land Use Act 1978, which confers ownership of all land to the Governors of each state and is a substantial deterrent to housing and housing investment in Nigeria. In actual fact, this right of occupancy is endorsed with a Certificate of Occupancy issued to the recipient. This often delays and adds significant costs to the registration process (Agbola 1987). An additional task in delivering affordable housing to low- and middle-income households is the affordability gap. Though some households attain affordability with additional informal income, this is not counted in loan origination procedures. Additional major issues affecting housing in Nigeria include inadequate access to finance, slow administrative procedures and the high cost of land registration and titling (Vuyisani 2003). The Nigerian housing sub-divisions need intervention in all aspects to ensure that it functions efficiently. One way to achieve this is through the introduction of inventive products like housing microfinance, which have been effectively adopted in other countries with similar macroeconomic indices (Olayiwola 2005 and Okupe 2002).

Adebayo (2005) stated that due to development and population growth with the subsequent serious shortage of housing, many Nigerian governments have provided housing among other national needs. The Nigerian federal government's housing policy was directed towards delivery of low-cost housing on a large scale, with the numerous states having related policies, and providing core housing and walk-up flats. The government also established satellite towns and government employee, high-rise apartments. The execution of these projects contributed greatly to housing delivery system. It has emerged that this housing approached was not sustainable over time due to the absence of a post-implementation strategy, as an integral part of the procurement and management system (Federal Republic of Nigeria 1991).

The objectives of the study are to assess the housing delivery system in Nigeria and to evaluate the housing need and demand. The methodology adopted for the study includes interviews and analyses of data collected during the field investigations. These investigations were complemented with review of literature. The data required for this study were obtained primarily from secondary source and personal observations. 


\section{Need for affordable housing}

Rapid growth in population creates demand pressure towards shelter and efficient supply and distribution of basic utilities and services for the city dwellers. In most of our urban centres, the problem of housing is not only restricted to quantity but to the poor quality of available housing units, the effect which is manifested in overcrowding of houses. Nigeria is perhaps the fastest urbanising country in the African continent. One of the most important challenges facing the country is the provision of affordable housing. As more and more Nigerians make towns and cities their homes, the resulting social, economic, environmental and political challenges need to be urgently addressed (Ajanlekoko 2001 and Raji 2008).

The housing situation in Nigeria puts existing housing stock at 23 per 1,000 inhabitant. Housing deficit is put at 15 million houses, while N12 trillion will be required to finance the deficit (Mabogunje 2003, 2004). This is about 4 times the annual national budget of Nigeria (Federal Housing Authority (FHA 2007). Home prices and rents, on the other hand, have grown ahead of general inflation. Making matters worse, the composition of homes for sale and rent on the market has been inexorably shifting towards very expensive home (Nubi 2008). The National Rolling Plan of 1990-1992 estimated housing deficit at 4.8 million. The 1991 housing policy estimated that 700,000 housing units are to be built each year if housing deficit is to be cancelled. In spite of a series of government policies towards housing delivery, one thing that is clear is that there exist a gap between housing supply and demand (Olomolaiye 1999; Agbola 1998; Adegeye and Dittoh 1985).

Historically, housing unit is treated as product hence the need for quality if it is to pair well and perform desirably in the market, but quality in construction industry suffers significant difficulty as it passes through extreme pressure driven by cost minimisation rather than value maximisation. Research has shown that $75 \%$ of urban housing is situated in slum conditions (urban development policies in Nigeria 1988), and indeed, the quality of the housing is poor and clearly an affront to human dignity. As part of effort to increasing qualitative housing for the masses in the country, the federal government of Nigeria (2004) pledged to adequately fund research pertaining to the manufacture and the use of local materials in the sector, with the aim of providing 40,000 houses, to at least 1,000 per state before year 2007 (Olutah 1997; Agbola and Olatubara 2003).

Housing delivery in Nigeria is provided by either the government or Private sector, but despite federal government access to factors of housing production, the country could at best expect $4.2 \%$ of the annual requirement. Substantial contribution is expected from other public and private sectors. It should be acknowledged that private sector developers account for most of urban housing (Federal Office of Statistics 1983). The production of housing in Nigeria is primarily the function of the private market; approximately $90 \%$ of urban housing is produced by private developers. Due to housing demand created by ruralurban migration, which account for $65 \%$ of urban population growth, the fixed supply of urban land, and inflation of rental and housing ownership cost (Taylor 2000). Unfortunately, the private sector is saddled with numerous problems which make supply always fall far short of demand and lower production quality (Nubi 2008). The problem of qualitative housing has been a concern for both the government and individuals. Appreciating these problems, both public and private sector developers make effort through various activities to bridge the gap between housing supply and demand, but the cost of building materials, deficiency of housing finance arrangement, stringent loan conditions from mortgage banks, government policies among other problems have affecting housing delivery significantly in Nigeria (Raji 2008; Bichi 1997 and Daramola 2004). 
With different Policies and user solutions that are abound for the purpose of reducing quantitative housing deficiency. It could be possible to solve the problem if housing were used only for shelter needs. However, in addition to serving as a shelter, housing is also a produced commodity, consumer good, assurance for families, means used for reproducing social relations and an investment tool protecting the value of money against inflation. Moreover, it is important that house is a building block in its relations with its environment, mutual interaction and increasing the quality of its environment when it is considered as part of the city. In this context, it can be accepted that a large housing stock is available today as a result of new presentation forms and production processes with a high volume of housing production. However, the existence of this stock shows that the housing policies are planned depending mostly on production (Okupe 2002).

\section{Institutional framework for housing}

Several public and private sector institutions are directly or indirectly involved in housing; however, there is a need for improved efficiency, collaboration and mechanisms to improve housing delivery. The institutional framework for housing is characterised by public, quasi-public and private sector organisations. The main public sector institutions involved in housing consist of government ministries/departments that provide the regulatory and administrative framework for housing delivery While the role of each ministry is necessary, the cumbersome and lengthy regulatory approval processes involved tend to limit the private sector participation in the housing industry because this process leads to inefficiencies, wastefulness, exploitation, delays and high project cost (Daramola 2004). In general, an inadequacy of financial and human resources is the main constraints to the efficient coordination, implementation and enforcement of the public sector's housing effort (Kihato 2009 and Ebie 2004).

\subsection{The Ministry of Lands, Housing and Urban Development}

The Ministry of Lands, Housing and Urban Development (formerly the Ministry of Housing, Urban Development and Environment) was created in 2002 with housing accorded for the first time a separate status free from the bureaucracy and financial stranglehold of the Ministry of Works. The Ministry of Lands, Housing and Urban Development's roles includes policy formation, setting standards for the sector, establishing building standards and codes for housing delivery, and safety in collaboration with relevant professional bodies (Enhancing Financial Innovation and Access 2008) (Table 1).

\subsection{Central Bank of Nigeria (CBN)}

The CBN is the apex regulatory authority of the financial system. It was established by the Central Bank of Nigeria Act of 1958 and commenced operations in July 1959. Among its primary functions, the CBN promotes monetary stability and a sound financial system and acts as banker and financial adviser to the federal government (Central Bank of Nigeria 2008). It is the banker of last resort to the licensed 24 banks and approves licences to financial institutions, which include Deposit Money Banks, Primary Mortgage Institutions, Microfinance Banks, Finance companies, Bureaus De Change, and Development Finance Institutions (Federal Republic of Nigeria 1991). In 2005, the federal government in 
Table 1 Key players in the Nigerian housing delivery

\begin{tabular}{|c|c|c|c|}
\hline $\mathrm{S} / \mathrm{NO}$ & Regulators & Financial institutions & Developers \\
\hline 1 & Central banks of Nigeria & $\begin{array}{l}\text { Federal mortgage bank } \\
\text { of Nigeria }\end{array}$ & Federal housing authority \\
\hline 2 & $\begin{array}{l}\text { Federal ministry of lands, housing } \\
\text { and urban development. }\end{array}$ & $\begin{array}{l}99 \text { Primary mortgage } \\
\text { institutions }\end{array}$ & 36 state Housing corporations \\
\hline 3 & Security and exchange commission & 24 deposit money banks & $\begin{array}{l}36 \text { state ministries of housing } \\
\text { and urban development }\end{array}$ \\
\hline 4 & $\begin{array}{l}\text { Federal and state ministry of lands, } \\
\text { housing and urban development. }\end{array}$ & $\begin{array}{c}\text { Commercial banks and } \\
\text { mortgage institutions }\end{array}$ & 800 real estate developer \\
\hline 5 & Central banks of Nigeria & $\begin{array}{l}\text { Federal mortgage bank } \\
\text { of Nigeria }\end{array}$ & 55 Insurance companies \\
\hline
\end{tabular}

Source: Adopted from Pison Housing Company (2010) and modified by the author

conjunction with the CBN set up the Financial System Strategy (FSS) and year 2020 Mortgage committee (Nubi and Omirin 2007).

\subsection{Federal mortgage bank of Nigeria (FMBN)}

The FMBN is the apex mortgage institution in Nigeria with a broad mandate as follows: Link the capital market with the housing markets. Encourage the emergence and promoting the growth of viable primary mortgage loan originators to serve the needs for housing delivery in Nigeria, mobilise domestic and foreign funds into the housing sector; collect and administer the National Housing Fund (NHF) in accordance with the provisions of the NHF Act, the NHTF, established in 1992, was aimed at addressing housing finance challenges in the low-income sector. It was formulated taking into consideration the housing demand gap and the difficulty of accessing finance (Anugwom 2005 and Bichi 1997). Through commercial banks and other financial institutions, it was granted a take-off fund of N250 million (US\$1.7 m). Key objectives of the fund include ensuring the provision of housing units is based on realistic standards that house-owners can afford, giving priority to housing programmed designed to benefit the low-income group and encouraging every household to own its house through the provision of credit or funding (Enuenwosu 1985; Akinlusi 2007; Nubi and Omirin 2007).

\section{Housing demand and supply}

Housing demand is the number of dwelling units that are actually needed by the people at a particular point in time, while housing supply is the number of residential units that are provided by the key players in the accommodation provision.

\subsection{Housing need and effective demand}

There is a gap in knowledge between requirement for housing and the ability to obtain the preferred housing type, which result in an effective request crisis for affordable housing in the country. Although it is clear there is a housing shortfall, it is fundamental to know that 
people can only obtain what they can meet the expense. Affordable housing to low- and middle-income households is the affordability gap. This is defined as the difference between the required monthly mortgage repayments on the least expensive house and the $33 \%$ (an industry standard as recommended by the International Labour Organisation) that can be deducted from the total salary of a potential homeowner. The gap affects $52 \%$ of the population or 65 million households. While some households achieve affordability with supplementary, informal income, this is not counted in loan origination procedures. Affordability analysis shows that low-income earners can afford housing units at N2 million $(\$ 13,333.33)$. Analysis of the stock of dwelling units helps to understand affordability. As at 1991, the total dwelling units in Nigeria was estimated at 15.2 million and more than $70 \%$ was in tenement rooms (called face-me-I-face-you) (see Table below). Unfortunately, there is no more recent data available. Since 2006, government intervention has been through public-private partnership (PPP) programmes (Daramola 2004). Prior to this, government was directly involved in constructing housing units. Housing demand is higher in the urban areas, which is about $40 \%$ of the population (Enhancing Financial Innovation and Access 2008) (Table 2).

\subsection{Housing demand}

Demand is influenced by several economic factors, such as increased economic activity that has led to increased demand for labour and rural-urban migration. The result is that there are 14 million units of housing deficit in the country. This is about a hundred per cent increase when compared to the deficit in 2001. There has been an intractable gap between government's supply efforts and actual achievement over the years, worsened by a population growth from about 42 million in 1960 to more than 151 million in 2010. Supply of housing units in Nigeria can be viewed from the formal and the informal sectors. The formal refers to supply from the private sector and the various elements of the public sector (Enhancing Financial Innovation and Access 2008) (Tables 3, 4, 5).

\subsection{Housing supply}

Various authorities have offered strategies for improving housing delivery in Nigeria. Fasakin (1998) suggested the co-operative housing model; Oduwaye (1998) advocated a simple land allocation system; Omole (2001) suggested an affordable financing model and

Table 2 Estimated housing stock, by dwelling types in Nigeria (1991)

\begin{tabular}{|c|c|c|c|c|c|c|}
\hline & Urban $\%$ & $\begin{array}{l}\text { Urban units } \\
\text { (million) }\end{array}$ & Rural \% & $\begin{array}{l}\text { Rural units } \\
\text { (million) }\end{array}$ & Total \% & $\begin{array}{l}\text { Total units } \\
\text { (million) }\end{array}$ \\
\hline Maisonette & 2 & 67 & 0 & 12 & 1 & 79 \\
\hline Duplex & 3 & 101 & 0 & - & 1 & 101 \\
\hline Detached bungalow & 10 & 337 & 20 & 2,289 & 17 & 2,627 \\
\hline Semi-detached & 2 & 67 & 1 & 60 & 1 & 127 \\
\hline Flat & 15 & 506 & 0 & - & 3 & 506 \\
\hline Tenement (Room) & 65 & 2,194 & 77 & 9,200 & 74 & 11,393 \\
\hline Others & 3 & 101 & 2 & 287 & 3 & 388 \\
\hline Total & 100 & 3,373 & 100 & 11,848 & 100 & 15,221 \\
\hline
\end{tabular}

Source: UN Habitat 2001. Report on National Housing Trend 
Table 3 Estimated housing needs (1991-2001)

Source: UN-Habitat ( 2001)

Table 4 Nigerian population and households_-2006

Source: National Bureau of Statistics (2007)

\begin{tabular}{|c|c|c|c|}
\hline & $\begin{array}{l}\text { Urban } \\
\text { areas }\end{array}$ & $\begin{array}{l}\text { Rural } \\
\text { areas }\end{array}$ & Total \\
\hline Housing stock 1991 ('000 units) & 3,373 & 11,848 & 15,221 \\
\hline $\begin{array}{l}\text { Estimated no. of households } 2001 \\
\text { ('000) }\end{array}$ & 7,289 & 15,295 & 3,916 \\
\hline Required output 1991-2001 ('000) & 22,584 & 3,447 & 7,363 \\
\hline $\begin{array}{l}\text { Required annual output, 1991-2001 } \\
\text { ('000) }\end{array}$ & 391.6 & 344.7 & 736.3 \\
\hline
\end{tabular}

\begin{tabular}{lll}
\hline $\begin{array}{l}\text { Population } \\
2006\end{array}$ & $\begin{array}{l}\text { Number of } \\
\text { households }\end{array}$ & $\begin{array}{l}\text { Population 2010 } \\
\text { (assumed growth } \\
\text { rate of 3.80\%) }\end{array}$ \\
\hline $140,431,790$ & $32,711,253$ & $163,025,239$ \\
\hline
\end{tabular}

Table 5 Housing supply structure

\begin{tabular}{lll}
\hline Formal (public sector) & Formal (organised private sector) & Informal sector \\
\hline Federal ministry of housing & Real estate developers & Individual \\
Federal housing authority & Primary mortgage institutions & Families \\
State ministry of housing & Corporate bodies & Co-operatives \\
State housing corporations & Real estate investment vehicles & Community \\
Local government housing & (trusts) development finance institutions & developments efforts \\
programmes & &
\end{tabular}

Source: Pison Housing Company (2010)

Igbinoba (2009) encouraged commercialising housing support services for the poor and low income. The 1991 Housing Policy estimated that 720,000 housing units would be built each year, but current estimates show that Nigeria needs an average of one million housing units a year to replenish decaying housing stock and also meet rising demand. The 1991 policy further indicated that not less than $60 \%$ of the new houses would be built in urban centres throughout the country (Federal Republic of Nigeria 1991). A study by Onibokun (1985) showed that $20 \%$ of most buildings in the urban areas of Nigeria were more than 25 years old. The same study confirmed that over $65 \%$ of houses were in the urban areas and that $90 \%$ of rural areas were developed by informal, individual efforts. Despite several housing policies and successive administrations, not much impact has been made by the federal government in affordable housing supply. At the state level, the housing corporation model has been used by the state governments in an attempt to deliver affordable housing (Aribigbola 2008) (Table 6).

\subsubsection{Housing corporations}

Virtually, every state has established state housing corporations to largely operate as property developers of the government. The corporations funding comes mainly from government budget allocations, and units are usually sold for cash. Often the middleincome earners are the target market for these developments. Buyers either pay cash or are allowed to make instalment payments during the period of construction, as mortgage 
Table 6 Assessment of impact of national housing programmes from 1975-1995

\begin{tabular}{lrll}
\hline Period & Planned & Achieved & $\%$ of achievement \\
\hline $1962-1968$ & 24,000 & 500 & 2.1 \\
$1970-1974$ & 54,000 & - & 0 \\
$1975-1980$ & 202,000 & 28,500 & 14.1 \\
$1981-1985$ & 200,000 & 47,200 & 23.6 \\
$1994-1995$ & 121,000 & 1,014 & 0.8 \\
\hline
\end{tabular}

finance is not provided. The cumulative results from all of these initiatives remain inadequate. For example, the Lagos State Development and Property Corporation, the most active state housing corporation in Nigeria has produced less than 25,000 units since inception about 35 years ago. In the first quarter of 2009, the Lagos State government announced that it intends to provide 40,000 housing units within the next 4 years and about 50 ha of land has been identified for some of these housing initiatives, which will be developed in partnership with private developers (Pison Housing Company 2010).

\subsubsection{Private developers}

Activities of private estate developers were concentrated in Lagos State in the early 1990s. Prior to that, private real estate developers had nominal success. A major operator between 1988 and 1993 was HFP Engineering Limited, which, under a joint venture agreement and using prefabricated technology, delivered over 2,500 units of housing including 1,434 units at Victoria Garden City, in Lagos. More recently, activities of private developers are now coordinated under the Real Estate Developers Association of Nigeria (REDAN). It comprises over 850 companies across the country.

\subsubsection{Non-governmental organisations}

A few non-governmental organisations (NGOs) are also involved in the supply of housing to the low-income and informal market. The following is some of the notable housing projects embarked upon by NGOs. MTNF low-cost housing project-Shelter for Comfort: In 2005, the MTN Foundation and Habitat for Humanity low-cost housing project was launched. The project was aimed at addressing poverty and homelessness through providing simple, decent and affordable houses to low-income earners. The foundation plans to build 600 low-cost housing units in blocks of 100 units in each of the six geo-political zones. Individuals will be able to acquire these houses by obtaining mortgages. The mortgage term is 15 years with the loan interest fixed over the period. One hundred units have been completed in New Karu, Nasarawa State (North Central). The second and third phases of the project will be in the south-east and south-west regions (World Bank 2010).

\subsubsection{Institutional and special housing needs}

Currently, the institutional housing stock comprises 21 units which include special education centres, homes for the elderly, orphanages, poor/relief houses and correctional facilities. From a total of 580 people in institutional housing in 2001, around 353 were "special needs" residents, implying a ratio of three persons per 1,000 of the household population. While this ratio is relatively small, the Social Policy for Human Development 
reported that the number of older persons living in poverty has grown significantly in recent years. The Country Review of Social Protection recommended the need to specially target the elderly and disabled by providing day care centres for the elderly. The production and management of special needs housing is usually sponsored by various nongovernmental organisations (NGOs) as well as civil society organisations with assistance from GOSL. The social policy has proposed a strategy of financial assistance and technical support for public sector and civil society organisations involved in care of the elderly, provision of shelters for homeless persons. The issue of institutional housing supply is cross-cutting, spanning several government agencies, particularly those involved in housing and community development, criminal justice as well as NGOs. Therefore, close collaboration will be required to facilitate the provision of institutional housing that is accessible, safe and disaster resistant (Pison Housing Company 2010).

\subsection{Factors responsible for high housing pricing trends}

There are several factors responsible for high house prices. These include land allocation costs, the high cost of funding, the high cost of building materials (cement and steel), logistical challenges and the dearth of skilled artisans. The price of land is beyond the reach of most individuals and even where government partners with developers, the land allocation costs and charges make it impossible to deliver the housing units at an affordable price for the low-income market. The site and services land acquisition programme in Lagos State has not been as effective as planned. House prices in Nigeria are also a function of location of the property. Both sales and rental prices are higher in urban areas than rural areas. This is why most low-income housing is located in suburbs of major cities. However, as the cities expand, these suburbs soon become part of the cities. In the past 10 years, values of properties have generally been on the increase $(15 \%$ a year for both sales and rental) until 2008 and early 2009 when prices in the middle- and upper-income segment fell by 30 to $40 \%$ depending on the location. Since then, they have stabilised around the crashed prices (Timothy 2000).

\section{Housing delivery and finance}

The Nigerian housing finance market is organised along informal and formal areas. The formal sub-division has two components: the upper-income groups, whose undertakings are located in the urban areas, and the lower-income groups which depend on the subsidised NHTF for access to housing. The informal area includes the rotating savings and loan associations, the traditional co-operative system, credit co-operatives and individual and family savings (Okonkwo 1999 and Bichi 1997). Several factors make the environment for mortgage lending difficult, including the absence of clear property and security rights, mandatory governor's consent, high interest rates and inadequate sources of long-term funding. Generally, there is indication of decreasing activities in housing finance: the average share of gross domestic product (GDP) invested in housing dropped from $3.6 \%$ in the 1970s to less than $1.7 \%$ in the 1990s (Pison Housing Company 2010).

\subsection{Current housing delivery approach}

In 2003, the federal government also established the Federal Ministry of Housing and Urban Development and proposed a housing reform, in view of the fact that there were not many 
affordable houses in Nigeria. There was an illusion that houses were available. But most of them were high-priced. There is a need for legislation to be amended substantially to bring their provisions in line with the new housing regime. The touchstone in such reviews is to reduce red-tape and ensure that various legislations are compatible with demands of a free and robust market economy (Mabogunje 2004). The period 2003-2004 witness a housing policy that recognised the private sector on the driving seat of housing delivery in the country, the key features of this policy include the placement of the private sector in a pivotal position, for the delivery of affordable houses, on a sustainable basis; assignment to government of the responsibility for the development of primary infrastructure for new estate development; and review the amendment of the Land Use Act to ensure better access to land and speedier registration and assignment of title to developers. Others are the development of a secondary mortgage market, involving the FMBN and the establishment of a new mortgage regime, under the NHF, to facilitate more favourable mortgage terms and a five-year tax holiday for developers (Enhancing Financial Innovation and Access 2008).

\subsubsection{Affordable housing scheme}

There are several affordable housing schemes that are either fully funded by government or in partnership with the government under the public-private partnership (PPP) scheme. In some cases, selected developers were given some kind of concession by government with the aim of providing affordable housing for instance, in the Federal Capital Territory. Such efforts were further complemented with the private finance initiative (PFI). Jibril(2009) further argued that while the quality of the existing stock is also under a heavy scrutiny in term design and desired functions including acceptable liveable neighbourhood, $87 \%$ of the existing stocks are backlogs which are stocks that do not meet the minimum quality requirement (Daramola 2004).

\subsubsection{Site and services scheme}

The pressure for this came from the international lending community and in particular the World Bank. Given the rising figures of "spontaneous or squatter settlements", in cities all over the third world, in the face of tight planning control, regular demolitions, and highcost construction programmes, the World Bank (2000) argued for a new approach to urban development which incorporated various forms of aided self-help; the two "packages" that received the most support were sites and services scheme, and upgrading schemes. Essentially, the first provided low-income beneficiaries with serviced plots including tenure security and help to build their own houses; the second approach helped houseowners in existing squatter areas obtains tenure to their land and to improve their dwellings. Many of these sites exist all over the country essentially provided by the government. And in spite of the fact that they may help to improve tenure security, the programme is capital-intensive in nature and the initial target population, low-income, usually do not benefit from them. The cost attached to each plot is usually beyond the reach of the urban poor (Igbinoba 2009 and Aluko 2002).

\subsection{Demands for housing finance}

Nigeria's housing deficit presents an enormous potential for housing finance investors. The country requires N49 trillion (US\$326 billion) to meet its housing demand. However, the 
outstanding credit to the economy as at December 2008 by financial institutions was put at $\$ 20$ billion. Outstanding mortgage loans are $0.5 \%$ of GDP in 2005, compared to $77 \%$ in US, $80 \%$ in UK, $50 \%$ in Hong Kong and $33 \%$ in Malaysia (World Bank 2010; Chamberlain 2005). Housing finance needs derive mostly from population growth in the urban areas of the country. With a rural urban migration rate of about $5.5 \%$, it is expected that Lagos, for instance, will reach 23.5 million by 2015. Generally, an increase in population translates into an increase in the demand for housing finance. Effective demand and home ownership relates to affordability, and this is based on household incomes (Kihato 2009; Chamberlain 2005).

\subsection{Supply of housing finance}

Lack of access to finance affects the supply of housing. Developers in the formal sector are mainly financed by deposit money banks at excessively high interest rates and stringent conditions. Low-income individual homebuilders seek finance either from informal sources such as ajo (traditional thrift societies) or esusu, age/trade groups, traditional moneylenders, friends or family to build their homes. Classified as microcredit organisations, these sources are convenient and accessible. They operate on the basis of third party guarantees and rely on peer pressure to ensure repayments. They are, however, unsecured and hardly accumulate the magnitude of funds required for large scale impact of individual household developments. In addition to the NHTF and primary mortgage institutions (PMIs), other suppliers of housing finance include Deposit Money banks, Development Financial Institutions, Insurance companies, Pension Fund Administrators and Housing cooperatives (Nubi 2000 and Bichi 1997).

\section{Key housing issues and constraints}

An analysis of the existing housing situation has revealed that there are several constraints facing the sector. Some of the critical issues which will need careful consideration and prioritisation in the formulation of a national housing policy are

\subsection{Unavailability of land for housing}

The relatively small size of the land resource base coupled with its historical and current pattern of ownership presents a serious constraint to housing. At every focus group discussion held in the various communities, the high price of land was identified as one of the major constraint to housing production. Therefore, land availability problem appears to be critical and deserving of special consideration. In particular, the various policy makers will need to address the challenge of improving the supply of affordable housing given a small finite land resource base. Consistent with the draft Land Use Policy, specific strategies and action plans relating to government's acquisition of available lands within communities will need to be examined in order to create housing land banks and consequentially focus on the needs of their residents. The acquisition of lands within communities for residential purposes should also be viewed within the sociological context of maintaining the community's cultural base (Aribigbola 2008). 


\subsection{High cost of infrastructure}

Another deterrent to housing production by both the private and public sectors is the high investment cost of land infrastructure particularly where the development is distant from existing infrastructure. The developer fully bears the high investment cost of provision of water and road infrastructure to a new site, without future benefits for connections made off these infrastructures to other sites by other individuals or developers. This high cost of infrastructure significantly influences the final price of the serviced land and ultimately, the cost of housing to the consumer. Therefore, there is a need to firstly re-examine the high initial cost of land infrastructure cost and secondly to develop a common approach for the provision of utilities to housing developments. The cost of infrastructure accounts for about $25-30 \%$ of housing expenditures. It is a main factor in the delivery of inexpensive housing. Authority has ignored this area and developers now deliver same, thus increasing the cost of houses. This is obvious in many gated residential communities across the populace, where the contractor provides autonomous electrical energy, water treatment plant, sewage plants, access roads to the estate, etc. (Pison Housing Company 2010).

\subsection{Increasing rural urban migration}

Rural-urban drift has not only placed a significant strain on the supply of housing, but has also resulted in severe traffic management problems. Indeed, the expressed demand for multi-family (apartment) housing in city is significant. Therefore, the recent proposals by central government to undertake renewal of some cities must be integrated within the proposed housing policy insofar as the housing aspects are concerned. At the macroeconomic level, a major challenge is the needed to promote economic development policies that will reduce the rate of urbanisation by providing more employment opportunities in rural areas (Aribigbola 2008).

\subsection{Inadequate finance mechanisms for low-income housing}

While a review of the housing credit sector indicates a reasonable supply of financial institutions, access by low-income households appears to be limited. In particular, households in the poorest income excluded from the formal credit sector. This is partly due to inflexible eligibility criteria for borrowing which involve steady income streams and land security. Therefore, appropriate mechanisms for financing low-income households must be leveraged, with particular emphasis on more realistic eligibility criteria and lower interest rates. Additionally, the institutional mechanism for administering low-interest finance to low-income households should be revisited. Given the fact that housing is one of the key basic human rights, attention is required with respect to the housing needs of the most vulnerable. While some housing assistance is provided through the government housing incentives, the mechanism for accessing these incentives remains largely unstructured. As a result, the benefits could be unintentionally diverted to higher-income groups. Therefore, it is important that clear incentive regimes be developed to specifically target low-income households. In that regard, there is a need for strategies and action plans to gather information on the socio-economic characteristics and geographic distribution of the poorest income quintile. More importantly, the specific allocation of funds through the annual national budgeting system is required for a focussed approach to affordable housing for low-income households (Anugwom 2005). 


\subsection{Inadequacy of administrative and legislative framework}

The situational analysis of housing delivery has revealed a highly disproportionate production of "low-income" housing during the last 10 years. Therefore, the public sector housing delivery institutions should urgently consider strategies for increased delivery of affordable housing to the low income, including beneficiaries of subsidies and the indigent. However, any national housing strategy and action plan should consider the development of methods which will enable the effective recovery of capital and recurrent cost from the beneficiaries of subsidised housing. Additionally, strategies need to be considered for the efficient and effective management of existing public rental housing to ensure financial sustainability of the public sector housing delivery system. Housing policy will need to reconsider rationalisation of all public and quasi-public organisations to ensure the efficient delivery of housing to all consumers. In that regard, attention should be given to the reestablishment of an institutional mechanism to facilitate continual dialogue among the various agencies and projects involved in housing, particularly for low-income households (Aribigbola 2008).

\subsection{Cumbersome regulatory approval process}

The lengthy and complicated regulatory approval process hinders efficiency within the housing delivery system. While certain measures instituted by the government are necessary, they tend to lengthen the regulatory process for obtaining planning approvals for land sub-division. In particular, the extensive delay caused by government referral agencies with respect to planning approvals has serious cost implications for private developers and ultimately, adversely affects in the final price to housing consumers (Ebie 2004).

\subsection{Lack of integrated planning in housing programmes}

In the absence of an explicit national development plan, housing sub-divisions simply involve the provisions of sites and services, houses and the allocation of a portion of land as an open space. This has resulted in the need for residents to travel relatively far distances to access services such as day care, transportation and shopping facilities. Therefore, the need for integrated planning of housing projects, whereby residents are provided with a full set of community facilities, is paramount in the development and sustainability of neighbourhoods. Essentially, government's planning agencies should play a more proactive role in the housing development process. Housing requirements should therefore be continuously assessed in terms of needs and their prioritisation, to influence national zoning plans and the creation of integrated development plans.

\subsection{Inadequacy of housing information system}

The deficiency of information, which has also been expressed on several previous occasions, is cause for deep concern since the formulation of any successful housing policy must be based on a reliable housing information system. Therefore, it is essential that financial and human resources be allocated to facilitate the development of a comprehensive, accessible up-to-date and transparent database on the housing market. Moreover, a database with qualitative and quantitative information on housing will also serve to measure the performance of the proposed NHP against established targets. 


\subsection{Limited private sector involvement}

The analysis of the housing situation has confirmed that private sector involvement has always been minimal, particularly in the production of low-income housing. There is also an absence of public-private sector partnerships in housing delivery. This situation exists despite several efforts by government, particularly in the form of fiscal incentives. The relatively high cost of undeveloped land, strict requirements and the cumbersome regulatory approval process are some of the deterrents posited for the low level of private sector involvement. Therefore, strategies should be developed to promote increased involvement of the private sector as well as to address the issue of public-private sector partnerships in the provision of housing with particular attention to low-income groups (Daramola 2004 and Ebie 2004).

\subsection{Inefficiency of house construction}

With materials and labour inputs representing almost equal proportions of the cost of house building, it is critical that these two production factors be affordable, readily available and efficiently utilised. In particular, attention is required in the development of strategies and action plans that would encourage the availability and utilisation of building materials, particularly from indigenous resources. In terms of contracting, the low entry barrier of the construction industry, lack of a regulatory body, absence of mandatory standards together with the non-existence of a legally binding building code has contributed to the general poor performance of contractors. This has been reflected in lengthy construction durations and poor quality of house building. Thus, in order to ensure that the proposed housing policy is all embracing, it is essential that construction quality management be appropriately addressed. In that regard, capacity building through training, registration and licensing of housing contractors and the enactment of the Building Code should be considered. This of course must be developed against the need for improved competitiveness within the environment and globalised economy (Ebie 2004).

\section{Challenges in accessing housing}

The Nigerian housing section has an affordability task. Housing provision is directed mainly at the middle- and high-income section of the populace that can either pay cash or access mortgage finance from the banks. The sheer proportion of the low-income people, nevertheless, proposes a crucial growth opportunity for developers and investors if they are adequately innovative. For the fact that the long-term finance for housing development is not available, this compels manufacturers of housing to recover their funds within the shortest possible time. In these circumstances, the development of non-mortgage housing finance products, such as housing microfinance, could be very usefully explored (Bichi 1997). Other tasks to the improvement of the Nigerian housing provision include

\subsection{Macroeconomic tasks}

Inflation in Nigeria is still in double digits. Investors, lenders and borrowers desire a stable economy where judgments can be taken without fear. Apart from price increases, other macroeconomic guides should be kept steady and must continue to develop if the mortgage market is to flourish and become effective. 


\subsection{Policy and regulatory tasks}

The Land Use Act of 1978 has become hindrance to making land accessible for housing. This issue has been responsible for the lengthy administrative procedure of securing the Certificate of Occupancy, the document that confers ownership of the land to the individual from the government. Also, the Act has not assured security of title, and cost remains prohibitive, while access to titled and registered land is problematic and burdensome.

\subsection{Taxes and fees}

The levy problem on housing provision and development in Nigeria is huge. Value added $\operatorname{tax}$ (VAT), which is deducted at numerous stages of the building approval, adds as much as $30 \%$ to the total cost of a house. This is exclusive of titling fees and stamp duties. This eventually places the sales price of the item beyond the reach of low-income recipients.

\subsection{Property registration and building approval}

Registering property and building approval is generally slow, burdensome and expensive. However, there has been some improvement since 2008 when the new reforms had led to a reduction in the time required to complete the process from 274 to 80 days.

\subsection{Financial sector tasks}

The insufficient resources and capital base of most primary mortgages limits their ability to deliver needed finance to meet housing demand (Okonkwo 1999).

\subsection{Capital challenges}

Finance is a major task in the Nigerian housing provision. Housing provision is characterised by high interest rates, which are a reflection of the source of funds which is mostly short tenured (30, 60 and 90 days). Housing finance where present is structured as variable rate mortgages. Funding tasks lead to affordability issues. Consequently, there is a gap between the price of houses and the earnings of end users.

\subsection{Inaccessibility of secondary market}

There is no well-organised secondary mortgage market linked to capital markets and institutional investors. This puts enormous burden on primary mortgage institutions or housing finance institutions to carry the mortgage loans to maturity. Presently, outstanding mortgage loans remain unpaid no matter the tenure. This confines the ability of the primary mortgage institutions to create more loans.

\subsection{Unavailability of credit enhancement vehicles}

To spread mortgages to low-income ranks, there needs to be some credit boost like mortgage insurance to guarantee credit risks up to certain loss levels for loans with high loan to value ratios. This may also extend affordability to the low-income population as creditors will require lesser deposits if the loan is certain. 


\subsection{Limited skilled manpower}

There is inadequate capability for the essential expertise required in the housing finance in Nigeria. This is explained by the fact that the market has not being in existence for a long time.

\subsection{Importation of building materials}

Continuous importation of building materials into the country which is about $60 \%$ of the building materials required for housing development. This is a significant factor for the high cost of houses in Nigeria.

\section{Guiding principles for implementation of housing delivery}

The successful resolution to housing delivery situation will require a comprehensive approach, which mobilises and harnesses the combined efforts of the private and public sectors as well as civil society. Therefore, the following guiding principles are essential for providing support for implementation of the housing delivery.

\subsection{Standards}

Planning standards are necessary to develop safe, disaster resistant and quality housing, especially to core need households who are particularly vulnerable to the effects of natural hazards.

\subsection{Affordability}

Housing must remain affordable in order to meet the satisfaction of all households, particularly those with a "core need". This is especially important since land and house prices, rent and construction costs have risen more rapidly than real incomes, thus reducing the housing options of low-income households. In addition, households' access to financing is a critical component of housing affordability, particularly in view of the eligibility criteria of many lending agencies.

\subsection{Partnering}

The mobilisation and harnessing of the combined resources, efforts and initiatives of public and private sectors, community organisations, civil society and the international community, is essential to housing all citizens. The contribution and commitment of the skills, labour, creativity, knowledge, and financial and other resources of all these stakeholders is critical to facilitate an enabling environment to house all citizens (Daramola 2004).

\subsection{Sustainability}

It is absolutely essential for the housing delivery process to be implemented on a sustainable basis, paying due regard to social, historical, economic and ecological concerns. Consequently, it is important that short-term housing solutions do not undermine the opportunities for future generations to circumvent the viability of any long-term 
interventions aimed at sustainable growth. Environmental, economic, fiscal, social, cultural, financial and political sustainability are imperative to facilitate an effective housing delivery process. Sustainability is necessary to satisfactorily meet the requirements of all citizens throughout their lifetime.

\subsection{Empowerment and self-sufficiency}

Housing does not only fulfil the basic need of shelter, but also plays a vital role in the economic and social health of the Nation. Economic growth and prosperity enhances the creation of integrated communities and fosters a sense of pride, which could encourage family self-sufficiency. The greater the ability of the household to be self-sufficient; the less the anticipated input or responsibility of government to support that household: In particular, housing represents a major asset for both the homeowner and the island as a whole. Since housing is often the single largest investment for most households, investment in housing is potentially the most fundamental pillar for extended social and economic expansion. Increased home equity contribution and consequently total household wealth is essential for national prosperity.

\subsection{Efficient land use}

The small and hilly land resource base demands increasing efficiency in land use in order to maximise the number of housing units and foster the provision of infrastructure in a cost-efficient manner.

\subsection{Housing information management}

An effective and transparent housing market can only be achieved through proper and effective housing information. In particular, pertinent information on the socio-economic status of households is necessary in developing meaningful strategies to address the housing situation. The collection and dissemination of housing data and information are imperative for proper decision making and analysis of existing and planned interventions.

\subsection{Desirability and variety}

The provision of a wide variety of housing solutions is necessary to facilitate choice, as well as consumer desirability. Housing solutions extend beyond the provision of houses and must therefore be sensitive towards the issue of desirable housing within communities where people want to live. It involves home extension, improvement and repairs; provision of serviced lots; evolutionary housing, such as core units, starter houses, foundations and slab; infrastructure upgrades; provision of health care services, child care centres and other social facilities and opportunities for employment.

\subsection{Priority areas for action}

In implementing the recommendations, focus will be placed on eight priority areas for action. These priority areas will form the basis for designing the strategic interventions required to implement the housing delivery. These priority areas involve the development of strategies or approaches to: improve the availability of land for housing, minimise the 
costs of housing infrastructure, reduce rural-urban migration, increase consumer-focussed housing, increase mechanisms for financing low-income households, strengthen the legislative and administrative framework for housing delivery, increase the participation of private sector, increase the efficiency of house production, determine the human, technical and financial resources required for implementation of housing policy and develop an effective information system to support decision making in housing delivery.

\section{Recommendations}

Nigeria's housing delivery depends on the active participation of both the public and private sectors. The following recommendations are required:

\subsection{Policy and regulation}

Difficulty in procuring consents for transfers, title deeds and very high processing costs. State governments should make administrative amendments to the Land Use Act to delegate endorsement of consent to Commissioners and at the national level, the director of lands should do this. There is need to simplify of land title registration by the revision of procedures and cost structure. Revised fee schedule should be capped at $0.5 \%$. Subsequent land transactions should not require Governor's consent but mere registration of title. Also the policies and programmes should be aimed at the low-income segment focusing on assisting them to acquire, build or improve their homes through easy accessibility to land and securing of title documents.

\subsection{Financial sector}

Housing microfinance for the low-income population is critical, and resources should be committed to researching and understanding this emerging sector. There should also be concerted technical assistance programmes and housing support services to be administered by the government. The CBN should direct PMIs to recapitalise to position them to finance big ticket transactions and to provide long-term funding to developers and end users. The CBN should also encourage Mergers and Acquisitions among PMIs. Institutionalise a code of corporate governance in the management of PMIs. CBN should issue a 20-25-year bond in collaboration with the Debt Management Office and use the proceeds to refinance eligible mortgages. FMBN should be given adequate resources by the government to strengthen its financial and operational capabilities (Okonkwo, 1999).

\subsection{Capacity building and knowledge gap}

The CBN, FMBN, Housing Finance Professionals Association of Nigeria (HOFPAN) and Mortgage Bankers Association of Nigeria (MBAN) should collaborate to institutionalise training leading to the certification of professionals in the mortgage and housing finance sectors. The National Universities Commission (NUC) should be encouraged to offer courses on housing finance at Universities. A Real Estate Information Centre that will warehouse data and information on the real estate and housing market should be established. The centre will be the repository of market information on key data in the housing 
sector. Capacity development and training for real estate professionals should be done through local and international training programmes, seminars, workshops and study visits.

\subsection{Housing sector}

The federal government should set up a housing infrastructural development trust fund to provide incentives to participating state governments to induce provision of housingrelated infrastructure in their states. Basic building materials should be given and tax and duty relief is given and government should develop incentives to encourage both the public and private sectors to use indigenous building materials. State and federal governments should engage housing finance experts to develop viable framework for public-private partnership for housing and infrastructure; government, developers and financiers should work together and come up with strategies that can make housing affordable especially to the low-income segment. Strategies may include granting tax holidays to developers and providing free land to them to reduce the cost of producing houses.

\subsection{Fairness}

Housing is considered a basic human need and right. It is therefore essential that equality and fairness in terms of access to housing be pivotal in the implementation of the housing policy particularly with respect to gender, youth, aged, indigent, physical disability and socio-economic status. Ensuring humane living conditions in the wider context of developing communities, especially for the needy, is essential in achieving housing for all.

\section{Conclusion}

The shortcoming of government's previous policies to address affordability issues is the curse of the housing delivery in Nigeria. Despite government's incapability to meet the housing need, the low-income people have been able to access housing in some form. Housing co-operatives have been able to deliver shelters to members where government and the organised private sector are unsuccessful. Their rise is partly because of the poor economic situation of the country. Housing co-operatives engaged in land acquisition, processing land title documents and obtaining building materials for their members. The co-operatives simplify the facilitation of house ownership for their members by giving them housing loans and constructing housing units (blocks of flats and tenement buildings) for members benefit. However, the rate and scale of their provision and supply is minimal compared to the housing need. Government should intervene and complete the reforms and provide incentives that will expand the scope of delivery of housing co-operatives.

Government should rally the related organisations, institutions and agencies to make available motivations, such as land use restructurings, grants, building materials cost discount programmes and tax reduction status that will ensure increased housing provision in the appropriate price bracket. Housing microfinance is another approach. Housing microfinance is a stimulating improvement suitable for the housing delivery. It serves the purpose of providing small, short-term loans to match step-by-step housing construction that the lower-income sector can pay for. Equally the public and private divisions should look critically at the issue of deploying housing microfinance in Nigeria. Remarkably, current evidence from the Central Bank of Nigeria shows that the microfinance policy in Nigeria is being updated to allow full-scale housing microfinance business models. 
Open Access This article is distributed under the terms of the Creative Commons Attribution License which permits any use, distribution, and reproduction in any medium, provided the original author(s) and the source are credited.

\section{References}

Adebayo, A. A. (2005). Sustainable construction in Africa. Agenda 21 positional paper.

Adegeye, A. S., \& Dittoh, J. S. (1985). Essentials of agricultural economics impact. Ibadan: Publishers Nigeria Ltd.

Agbola, T. (1987). Institutional constraints on housing development: The urban areas of Nigeria, the landuse decree and the building plan approval process. Habitat International, 11(2), 113-120.

Agbola, T. (1998): The Housing of Nigerians: A Review of Policy Development and Implementation. Research Report, 14, Development Policy Centre, Ibadan.

Agbola, T. \& Olatubara, C. O. (2003). Private sector driven housing delivery (in Nigeria): Issues, constraints, challenges and prospects. A lead paper presented at the 2 nd annual national workshop on private sector driven housing delivery in Nigeria, University of Lagos, Lagos, 30th-3rd July.

Ajanlekoko, J. A. (2001). Sustainable housing development in Nigeria. The financial and infrastructural implication presented at the international conference on spatial information for sustainable development, 2-5 October 2001, Nairobi, Kenya.

Akinlusi, A. (2007). Mortgage facilities; a Panacea for mass housing development. A paper presented at Nigerian Institute of Building conference, Lagos, November, 13, pp. 9-16.

Aluko, B. T. (2002): Urban housing for low income earners in cities of Lagos state: The land question: Proceedings of a national conference on the city in Nigeria, faculty of environmental designs and management, Obafemi Awolowo University, pp. 288-294.

Anugwom, E. E. (2005). Privatization of workers housing provision: The national housing fund scheme in Nigeria for African training and research centre in administration for development.

Aribigbola, A. (2008). Housing policy formulation in developing countries: Evidence of programme implementation from Akure, Ondo State Nigeria. Journal of Human Ecology, 23(2), 125-134. KamlaRaj.

Bichi K. M. (1997). Housing finance in the context of vision 2010. Housing Today. Journal of the Housing Co-operation of Nigeria, 4, 30-35.

Central Bank of Nigeria (2008). Annual report.

Chamberlain, S. P. (2005). Ameliorating housing deficit in Nigeria. The Role of Primary \& Secondary Mortgage Institutions and the Capital Market. http://nigeriaworld.com/feature/publication/peterside/ 072005.html.

Daramola, S. A. (2004): Private Public participation in Housing delivery in Nigeria, paper presented at a business luncheon organised the Royal Institute of Surveyors (RIS) in Chinese restaurant, Palmgroove, Lagos. 15, April, 2004.

Ebie, S. P. (2004). Statutory component(s) on housing policy; legislative and regulatory requirements of the new housing policy. Housing Today, 4(8), 6-9.

Enhancing financial innovation and access (2008): Access to financial services in Nigeria National Survey.

Enuenwosu, C. E. (1985). The federal mortgage bank of Nigeria: Its objectives and future prospects. Central Bank of Nigeria Bullion July-September, 1985. (pp. 20-25).

Falegan, S. B. (1980). Problems and prospects of the federal mortgage bank of Nigeria. Central Bank of Nigeria Bullion April-June, 1980. (pp. 32-36).

Fasakin, J. O. (1998). Cooperative housing; the concept, experience and applicability to Nigeria's socio economic milieu'. Seminar paper presented at the Federal University of Technology, Akure.

Federal Government of Nigeria. (2004). National housing policy draft, Abuja.

Federal Office of Statistics. (1983). Social statistics in Nigeria. Lagos: FOS.

Federal Republic of Nigeria. (1991). National housing policy federal ministry of works and housing.

Igbinoba, R. (2009). Investment Opportunities in Housing Development in Africa. Pison Housing Company Ltd. IGICA International Conference, Abuja, Nigeria; 8-10 June 2009 Book of Proceeding. (pp. 178-184). http://www.kfint.com/igica/files/IGICA\%20Proceedings.

Jibril, I. (2009). Squatter resettlement/relocation programme in Abuja, Nigeria and the issue of land title security. FIG Conference paper May 3th-8th. Eilat, Isreal.

Kihato, M. (2009). Scoping the Demand for Housing Microfinance in Africa: Status, Opportunities and Challenges (December 3, 2009). Finmark Trust. Available at SSRN: http://ssrn.com/abstract=1517715 or http://dx.doi.org/10.2139/ssrn.1517715. 
Mabogunje, A. L. (2003). The new mass housing and urban development policy: Social and economic impact. Being text of a public service lecture delivered to the top echelons of the federal civil service. Abuja, Nigeria. September 30, 2003.

Mabogunje, A. (2004). Housing delivery problems in Nigeria. Punch, Wednesday, May, 2002.

National Bureau of Statistics. (2007). The middle class in Nigeria; analysis of profile, determinants and characteristics (1980-2007).

Nubi, O. T. (2000). Housing finance in Nigeria: Need for Re-engineering. Ideal Habitat Cooperative Housing Initiative. Available at www.housingfinance.org/pdfstorage/Africa. Accessed 14 July 2012.

Nubi, O. T. (2008). Affordable housing delivery in Nigeria; The South African Foundation International conference and exhibition. Cape Town, October, (pp.1-18).

Nubi, T. O., \& Omirin, M. M. (2007). The role of primary mortgage institutions in housing delivery. Housing finance international, 21(5), 52-56.

Oduwaye, A. O. (1998). Beyond structural adjustment programme: Strategic options for increasing housing stock in Nigeria.

Okonkwo, O. (1999). Mortgage Finance in Nigeria. Esquire Press Ltd.

Okupe, O. (2002). Problem of real estate developers in Nigeria. A paper presented at a workshop organised by the Nigerian Institute of Quantity Surveyors. Abuja.

Olayiwola, L. M. (2005). Public housing delivery in Nigeria: Problems and challenges. A paper presented at the 'World congress on housing transforming housing environments through the design', 27-30 September, Pretoria, South Africa.

Olomolaiye. (1999). Rural housing in Nigeria; concept, problems and functional approach. Journal of the Nigerian Institute of Town Planners, $I V \& V, 20-30$.

Olutah A. O. (1997). The house: Accessibility and development-A critical evaluation of the Nigerian situation: Proceedings of National symposia on Housing in Nigeria; Obafemi Awolowo University Ile Ife, pp. 312-317.

Omole, F. K. (2001). Basic issues in housing development. Ondo: FemoBless Publishers.

Onibokun, R. (1985). Urban housing in Nigeria. Ibadan: NISER.

Pison Housing Company. (2010). Overview of the housing finance sector in Nigeria. Commissioned by EFInA and FinMark, Finmark Trust (Vol. 1, pp. 15-20).

Raji, O. (2008). Public and private developers as agents in urban housing delivery in sub-Saharan Africa. The situation in Lagos state. Humanity of Social Sciences Journal, 3(2), 143-150.

Taylor R. (2000). Urban development policies in Nigeria.

Timothy, O. N. (2000). Housing finance in Nigeria need for re-engineering, ideal habitat cooperative initiative.

UN Habitat. (2001). National Trend in Housing Production Practices (Vol. 4, pp. 60-69). Nigeria: United Nations Centre for Human Settlements. http://www.chs.ubc.ca/archives/files/HS-313.pdf.

Urban development Policies in Nigeria. (1988). Planning, housing and land policy. A report of the Centre for Economic Research on Africa. December, 2008, pp. 1-12.

Vuyisani, M. (2003). Preview of housing finance systems in four different African countries: South Africa, Nigeria, Ghana and Tanzania.

World Bank. (2000). Nigeria financial Sector Review; Volume 3: Non-Bank Financial Institutions and Markets.

World Bank. (2010). World development indicators. 